\title{
Male Movement Patterns and Bioacoustic Activity of the Western Cuban Grassfrog, Eleutherodactylus varleyi (Anura: Eleutherodactylidae)
}

\author{
Antonio Cádiz ${ }^{1,2}$ and Manuel Iturriaga ${ }^{3}$
}

${ }^{1}$ Departamento de Biología Animal y Humana, Facultad de Biología, Universidad de La Habana, La Habana, Cuba

${ }^{2}$ Sackler Institute for Comparative Genomics, American Museum of Natural History, New York, New York, USA

32División de Colecciones Zoológicas, Instituto de Ecología y Sistemática, La Habana, Cuba (manueliturriaga@ecologia.cu; manueliturriaga83@gmail.com)

\begin{abstract}
In this study, we examined movement patterns, vocal activity, and variation in advertisement calls at individual and populational levels in a population of Western Cuban Grassfrogs (Eleutherodactylus varleyi) at the National Botanical Garden of Cuba in July and September in 2007. Males appear to be very sedentary with peaks of movement early in the night and just before dawn that could be related with the search of calling sites and diurnal retreats, respectively. We detected eight patterns of frequency modulation of advertisement calls for note 1 and six for note 2. Patterns II and VI were the most frequent for note 1 and note 2, respectively. Note duration was the only acoustic parameter that was significantly variable among individuals for note 1 , whereas the maximum frequency and rise time were significantly variable within individuals for note 2 , suggesting that the latter is more reliable for distinguishing individual calls.
\end{abstract}

$\mathrm{P}$ opulation biology in amphibians is closely related to movement patterns (e.g., Duellman and Trueb 1994; Vitt and Caldwell 2014), with movements largely linked to searches for food, bodies of water, diurnal retreats, and mating, calling, or reproduction sites (e.g., Duellman and Trueb 1994; Wells 2007). Movement patterns can be affected by environmental variables, availability of food, responses to predators, and interactions with individuals of the same or different species (e.g., Wells 2007; Pough et al. 2016). On the other hand, advertisement calls of anurans are species-specific (e.g., Duellman and Trueb 1994; Gerhardt 1994), although they can exhibit intra- and interpopulational variations (Jang et al. 2011; Rodríguez et al. 2012, 2015). The former are closely linked to sexual selection (Bee et al. 2010; Meuche et al. 2013) or the recognition of conspecific males (Bee et al. 2010; Dautel et al. 2011; Alonso et al. 2017).

Cuba is home to 57 currently recognized species of frogs belonging to the genus Eleutherodactylus (Rodríguez et al. 2017). Several bioacustic and ethological studies have addressed these frogs (Alonso and Rodríguez 2001; Alonso et al. 2007; Díaz and Cádiz 2007; Rodríguez et al. 2010), but only Alonso et al. (2001) addressed anuran movement patterns and vocal activity during the nocturnal cycle.

The endemic Western Cuban Grassfrog (Eleutherodactylus varleyi; Fig. 1) is widely distributed in western and central

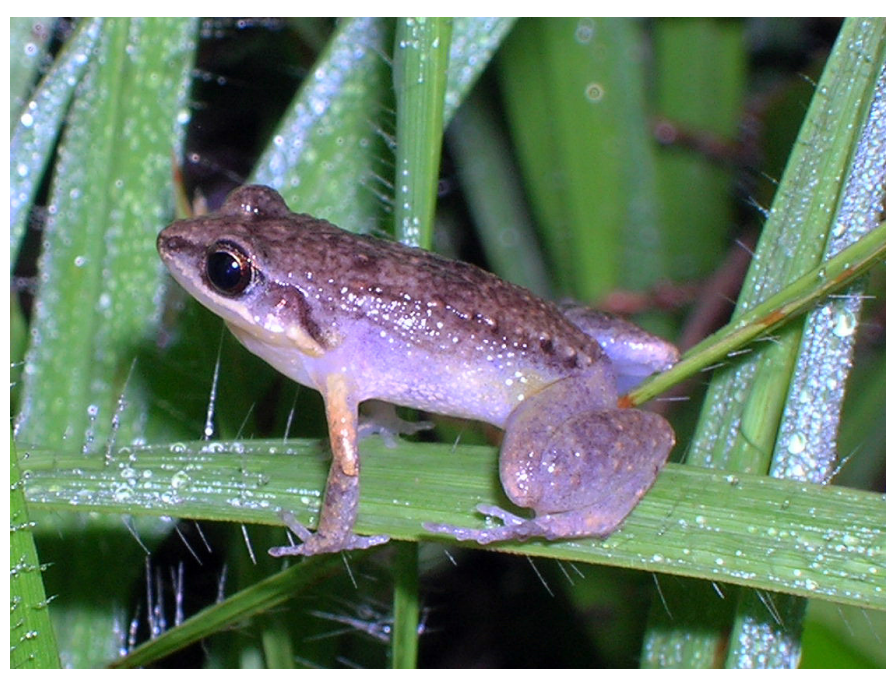

Fig. 1. A Western Cuban Grassfrog (Eleutherodactylus varleyi) from the Guamuhaya Massif in central Cuba. Photograph by Manuel Iturriaga.

Cuba (Díaz et al. 2012). Some aspects of its natural history suggest the existence of territories and individual discrimination mediated by acoustic recognition. Among these, for example, are physical confrontations between males while defending calling sites (personal observations of the authors), putative aggressive calls emitted sporadically (Díaz et al. 
2003), a breeding season extending several months that could lead to the establishment of long-term interactions between neighboring males, and low mobility (personal observations of the authors) within putative territories, since these sites presumably encompass adequate food and shelter as well as suitable sites for mating and ovipositioning by females. Therefore, we herein characterize the movement patterns and vocal activity of a population of $E$. varleyi in western Cuba. We also describe variation in advertisement calls by individuals and between males to analyze the potential of acoustic emissions for social discrimination.

\section{Materials and Methods}

Study location and environmental parameters.-We conducted this study in July and September 2007 in a grassy area (grasses averaged about $30 \mathrm{~cm}$ in height) in the National Botanical Garden of Cuba $\left(82^{\circ} 20^{\prime} 24.98^{\prime \prime} \mathrm{W}, 22^{\circ} 59^{\prime} 54.91^{\prime \prime} \mathrm{N}\right.$; datum NAD27), Havana, Cuba. We measured air temperatures $\left(\mathrm{T}_{\mathrm{a}}\right)$, relative humidity $(\mathrm{RH})$, and light intensity $\left(\mathrm{L}_{\mathrm{i}}\right)$ at 30-minute intervals from 2000 to $0700 \mathrm{~h}$ (Fig. 2) at each sampling session using a NO9AQ multifunctional environmental meter $\left(\mathrm{T}_{\mathrm{a}}=0.1^{\circ} \mathrm{C} ; \mathrm{RH}=0.1 \%\right.$ and $\mathrm{L}_{\mathrm{i}}=0.01$ lux $)$.

Patterns of movements. - We tagged 12 individuals (7 in July and 5 in September) with UV-fluorescent pigments (Tritart UV powder pigments, light pink color) and measured snout-vent length (SVL) with a caliper to $0.05 \mathrm{~mm}$. The pigment was diluted in water and one drop was gently applied to the dorsum of each frog, initially located by advertisement calls. Once marked with fluorescent pigment, we used a UV-lamp with two 6-W tubes to locate each male that resumed calling after $15 \mathrm{~min}$ every $30 \mathrm{~min}$ from $2000 \mathrm{~h}$ to $0700 \mathrm{~h}$. This marking system allowed focal observations for one night but faded quickly, preventing observation on consecutive nights. Three categories were defined to quantify the position of each individual on the vertical axis: (a) high (apical end of the grass), (b) medium, and (c) low (at or very near ground level). The position on the horizontal plane was determined using a system of coordinate axes $(\mathrm{X}, \mathrm{Y})$ consisting of two graduated rods (1-cm precision) $250 \mathrm{~cm}$ in length,

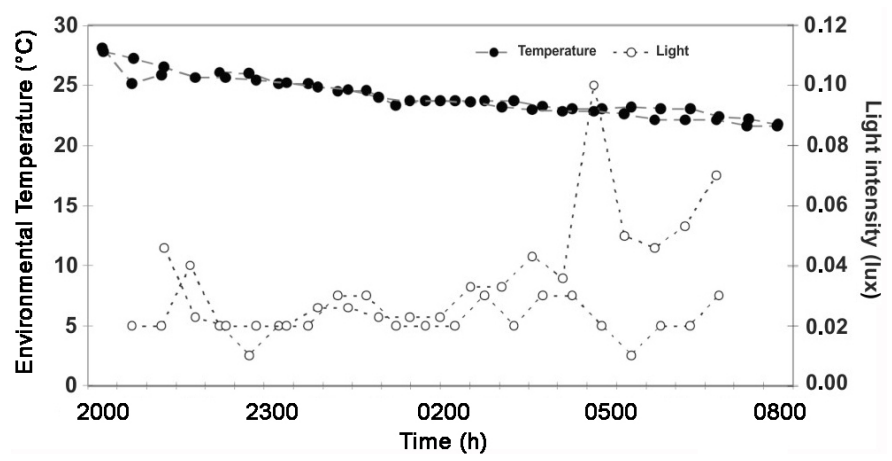

Fig. 2. Variation of environmental temperature $\left({ }^{\circ} \mathrm{C}\right)$ and light intensity (lux) at night in July and September in a grassy area of the National Botanical Garden of Cuba, Havana, Cuba. located perpendicular to each other and the center of which was located as close as possible to the initial site where each individual was found and tagged. Individuals that were more than $5 \mathrm{~m}$ from each other were selected to avoid overlapping in their home ranges and thus minimizing disturbances during our frequent visits.

Vocal activity and acoustic analysis of advertisement calls.-Using normal (Type II) 60-minute tape cassettes, we recorded the chorus ( 2 nights in July and one night in September) for $2 \mathrm{~min}$ at 30-minute intervals between $2000 \mathrm{~h}$ and 0700 h using a Marantz PMD 222 recorder and a Sony ECM 222 omnidirectional microphone placed at a height of $50 \mathrm{~cm}$. The number of acoustic signals in the 30-sec intervals of each recording was counted with the program Raven Pro 1.3 (www.birds.cornell.edu/raven). The intensity of the vocal activity was assumed to be a parameter that was a function of the number of acoustic signals recorded, and that depended on both the number of males that were simultaneously vocalizing and their call rates.

For the acoustic analysis, we recorded 20 males from $2000 \mathrm{~h}$ to $0400 \mathrm{~h}$ in July using an ultra-directional Sennheiser microphone coupled to the same acoustic recorder. The air temperature was registered in situ with a mercury thermometer $\left(0.1^{\circ} \mathrm{C}\right.$ precision). Calls were digitized with a sampling frequency of $22050 \mathrm{~Hz}$ and a sample size of 16 bits, using the program BatSound 2.1 (Petterson Elektronic AB, (C) 1996-1999) and for acoustic analysis of the calls we used the program Raven Pro 1.3.

We analyzed 15 two-notes calls for each male, measuring the following acoustic parameters: (1) call duration (time interval between the beginning and the end of the call), (2) note period (time interval between the beginning of a note and the beginning of the next note), (3) central frequency (dividing the signal into two frequency intervals of equal energy), (4) central time (point at which the signal is divided into two intervals of time of equal energy), (5) peak frequency (frequency of maximum energy), (6) rise time (point inside the signal in which the maximum amplitude is reached for the first time), (7) fall time (point in the signal at which the minimum amplitude is reached), (8) minimum frequency (lowest frequency value within the signal), (9) maximum frequency (highest frequency value within the signal), (10) frequency variation (difference between the lowest and highest frequencies within the signal), and (11) note duration (time interval between the beginning and end of the note).

Statistical analyses. - For statistical analyses we used the programs Statistics 6.0 (StatSoft Inc. 2001) and Infostat 1.1 (InfoStat 2002). For temporal and spectral variables of the advertisement call and data normality and homogeneity of variance we used Shapiro-Wilk's W and Levene tests, respectively. We employed a Spearman correlation to verify associations between both air temperature and SVL with acoustic parameters and chi-square tests to evaluate the frequency of 
frog position in the vertical axis at four time intervals: (1) 2000-1030 h, (2) 1100-0130 h, (3) 0200-0430 h, and (4) 0500-0700 h.

We studied the individual distinctiveness of advertisement calls using procedures previously described by Bee and Gerhardt (2001) and Bee et al. (2001). Briefly, for each male $(\mathrm{n}=20)$, we determined the individual mean $\left(\mathrm{X}_{\mathrm{w}}\right)$ and standard deviation $\left(\mathrm{SD}_{\mathrm{w}}\right)$ of each call property, and we used those values to calculate a within-individual coefficient of variation $\left(\mathrm{CV}_{\mathrm{w}}=100 \% \times \mathrm{SD}_{\mathrm{w}} / \mathrm{X}_{\mathrm{w}}\right)$. Also, for each acoustic parameter of each note of the call, we determined a grand mean and standard deviation based on the average of the 20 individual means from our sample, and we used these values to calculate the among-individual coefficient of variation $\left(\mathrm{CV}_{\mathrm{a}}=100 \%\right.$ $x$ grand SD/grand X). Finally, we determined the ratio of among-individual and within-individual variation as $\mathrm{CV}_{\mathrm{a}}$ I $\mathrm{CV}_{\mathrm{w}}$. To compare acoustic properties, we applied a univariate analysis of variance (ANOVA).

\section{Results}

Patterns of movements. - Individual Eleutherodactylus varleyi showed a general tendency to remain at the same site during the nocturnal cycle. The average number of movements in both months was only 3 (Table 1), with one extreme case of a frog that remained at the same site from $1200 \mathrm{~h}$ to $0630 \mathrm{~h}$.

Neither total distances moved $(\mathrm{t}=1.3, \mathrm{p}=0.11)$ nor distances between two consecutive sites $(\mathrm{t}=1.34, \mathrm{p}=0.12)$ differed significantly by month. However, in September we noted a tendency to decrease both the total distance moved and the distance between two consecutive sites. In both months, the distances between two consecutive sites varied considerably (Table 1).

The frequency of movements in the horizontal axis tended to be highest early in the night, when frogs made horizontal movements in $71 \%$ of the observations between 2200 $\mathrm{h}$ and $1130 \mathrm{~h}$. Movements subsequently decreased through the night before increasing again after $0500 \mathrm{~h}$ (Fig. 3).
Frogs showed a general tendency to remain most of the night in the same site, with animals not moving in $70 \%$ of the observations (Fig. 4). Most horizontal movements were less than $50 \mathrm{~cm}$. We did detect a nocturnal cycle of ascent

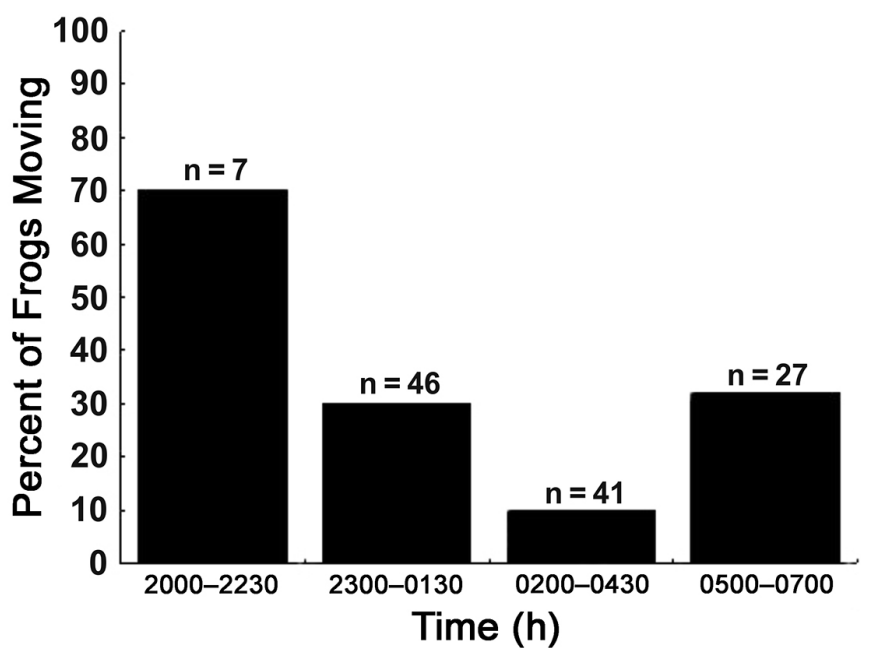

Fig. 3. Percent of 12 individually marked male Western Cuban Grassfrogs (Eleutherodactylus varleyi) moving during four nighttime intervals in a grassy area of the National Botanical Garden of Cuba, Havana, Cuba. The number of observations during each interval $(n)$ is indicated.

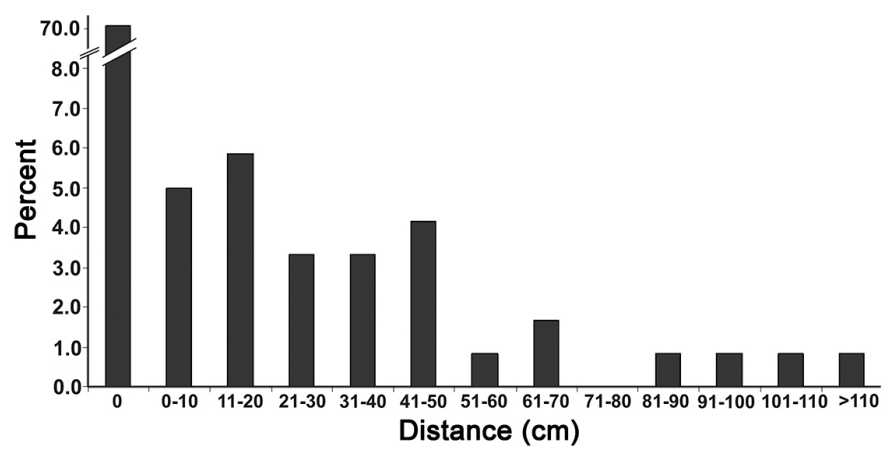

Fig. 4. Percent of 12 individually marked male Western Cuban Grassfrogs (Eleutherodactylus varleyi) moving various horizontal distances between two consecutive perches in a grassy area of the National Botanical Garden of Cuba, Havana, Cuba.

Table 1. Variables characterizing movements of Western Cuban Grassfrogs (Eleutherodactylus varleyi) in a grassy area of the National Botanical Garden of Cuba, Havana, Cuba. Means are presented \pm one standard deviation, $n=$ sample size, $F_{\mathrm{i}} \mathrm{Mov}=$ individual frequency of movement, and $\mathrm{CV}_{\mathrm{i}}=$ coefficient of individual variation.

Month

\begin{tabular}{|c|c|c|c|c|c|c|}
\hline & $\begin{array}{c}\text { July } \\
\text { Mean (range) }\end{array}$ & $\mathbf{n}$ & $\begin{array}{c}\text { September } \\
\text { Mean (range) }\end{array}$ & $\mathbf{n}$ & $\begin{array}{c}\text { Total } \\
\text { Mean (range) }\end{array}$ & $\mathbf{n}$ \\
\hline $\mathrm{F}_{\mathrm{i}} \operatorname{Mov}(\%)$ & $42.3 \pm 6.0(28.6-66.7)$ & 7 & $17.2 \pm 5.5(0-27.3)$ & 5 & $31.9 \pm 5.5(0-66.7)$ & 12 \\
\hline Total distance moved $(\mathrm{cm})$ & $142.0 \pm 39.1(57.0-329.0)$ & 7 & $76.2 \pm 31.2(0-181.0)$ & 5 & $114.6 \pm 27.0(0-329.0)$ & 12 \\
\hline $\mathrm{CV}_{\mathrm{i}}(\%)$ & $79.8 \pm 3.8(65.3-89.5)$ & 5 & $88.8 \pm 4.1(83.4-99.3)$ & 3 & $83.2 \pm 2.9(65.3-99.3)$ & 8 \\
\hline
\end{tabular}


and descent in the vegetation (Fig. 5) and a statistically significant relationship between the frequency of vertical movements and time $\left(\mathrm{c}^{2}=47.5, \mathrm{gl}=6, \mathrm{p}<0.001\right)$. Between 2200 $\mathrm{h}$ and $2330 \mathrm{~h}$, frogs were at medium heights in the grass in $60 \%$ of observations and at maximum heights in $25 \%$ of observations. Between $0000 \mathrm{~h}$ and $0230 \mathrm{~h}$, frogs in $64 \%$ of observations were at maximum heights and in $58 \%$ of observations between $0500 \mathrm{~h}$ and $0630 \mathrm{~h}$, frogs were on or near the ground.

Relative humidity was always high, with values ranging from $89.7 \%$ to $100 \%$ around $2300 \mathrm{~h}$. Temperature dropped

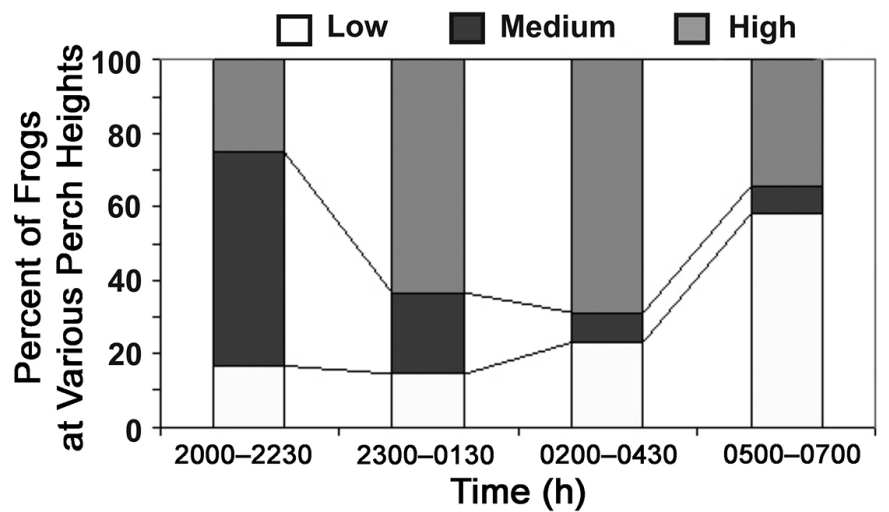

Fig. 5. Percent of 12 individually marked male Western Cuban Grassfrogs (Eleutherodactylus varleyi) at perches of varying heights during the night in a grassy area of the National Botanical Garden of Cuba, Havana, Cuba. gradually in both sampling periods from $28.1^{\circ} \mathrm{C}$ to $21.6^{\circ} \mathrm{C}$. Perceptible variations in environmental parameters between months were evident. The small nocturnal variations in light intensity were attributable to changes in cloud cover.

Vocal Activity. - We observed as many as five peaks of vocal activity in July, with the most intense occurring between $0200 \mathrm{~h}$ and $0330 \mathrm{~h}$ (Fig. 6). Vocal activity was also high at $2030 \mathrm{~h}, 2300 \mathrm{~h}$, and $0600 \mathrm{~h}$. The number of acoustic signals throughout the night varied between the two sampled months. Although a clear decrease in vocal activity was observed in September, the peaks at the beginning and the end of the night were still evident.

Advertisement call repertoire and individual variation.The descriptive statistics of acoustic parameters of advertisement call are summarized in Table 2. None of the acoustic parameters of the advertisement call were significantly correlated with the SVL of callers. However, air temperature was significantly correlated with call duration $\left(\mathrm{r}_{\mathrm{s}}=-0.62, P<\right.$ $0.05)$, interval between calls $\left(\mathrm{r}_{\mathrm{s}}=-0.64, P<0.05\right)$, duration of note $1\left(\mathrm{r}_{\mathrm{s}}=-0.55, P<0.05\right)$, and rise time of note $1\left(\mathrm{r}_{\mathrm{s}}=\right.$ $-0.70, P<0.05)$. Both notes of the advertisement call varied in spectral design. Note 1 showed eight patterns of frequency modulation, whereas note 2 had six (Fig. 7). For note 1, pattern II was the most frequent (45\%) and patterns V and VIII were the least commonly observed $(<4 \%)$. For note 2 , the most frequent pattern of modulation was VI (46\%), whereas the least commonly observed were I and III $(<3 \%)$.

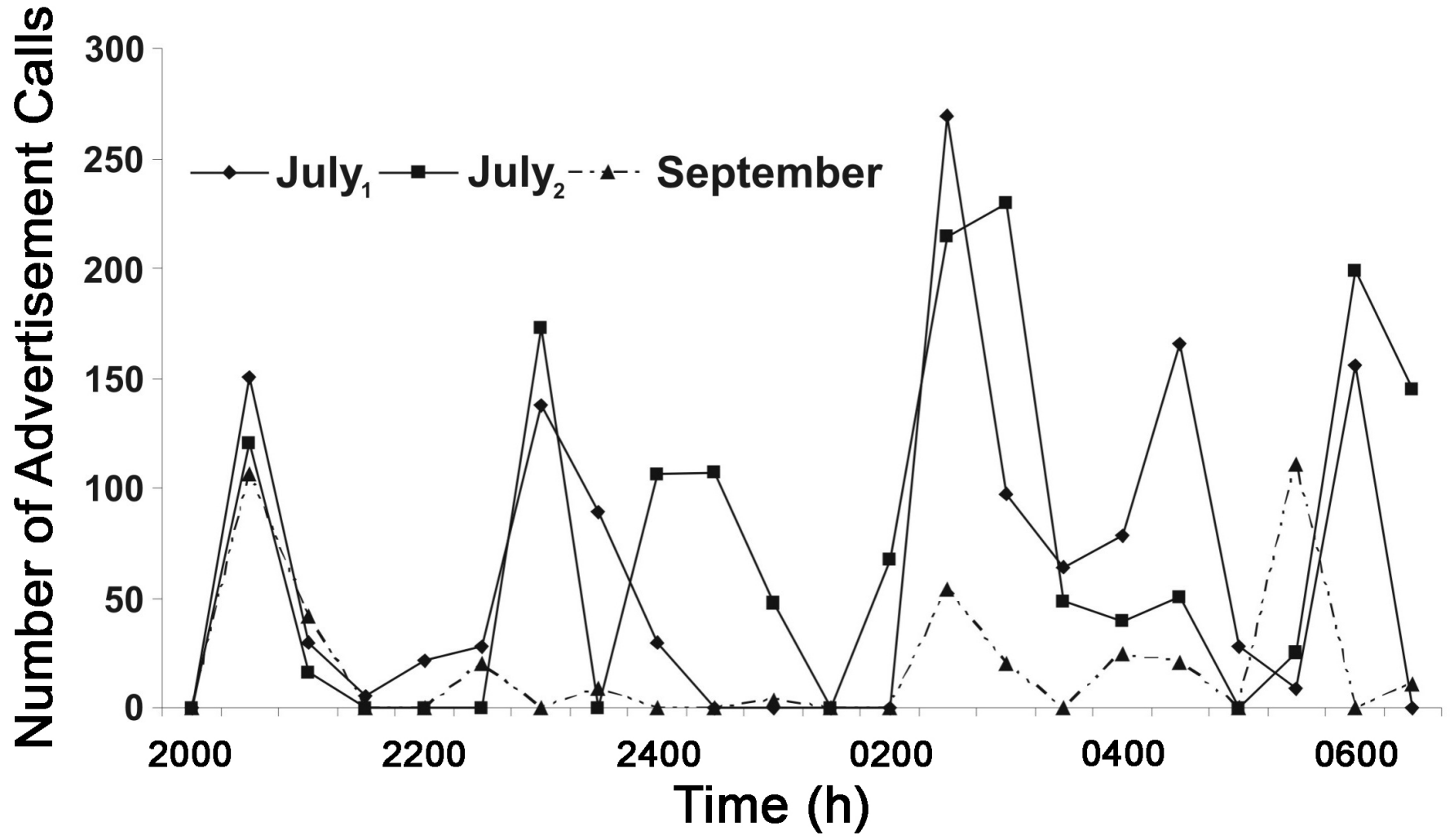

Fig. 6. Number of advertisement calls in choruses of male Western Cuban Grassfrogs (Eleutherodactylus varleyi) during sampling periods in July and September in a grassy area of the National Botanical Garden of Cuba, Havana, Cuba. 
Table 2. Acoustic parameters that characterize the advertisement call of Western Cuban Grassfrogs (Eleutherodactylus varleyi) in a grassy area of the National Botanical Garden of Cuba, Havana, Cuba. Means are presented \pm one standard deviation.

Acoustic parameters

Note 1: Mean \pm SD (range)

Note 2: Mean \pm SD (range)

\begin{tabular}{lcc} 
Minimum frequency $\mathbf{( H z})$ & $3,813.1 \pm 67.2(3,409.3-4,343.5)$ & $4474.3 \pm 98.6(3,739.3-5,100.9)$ \\
\hline Maximum frequency $\mathbf{( H z})$ & $4,735.9 \pm 77.1(4,160.9-5,282.8)$ & $5616.1 \pm 47.2(5,270.6-5,976.8)$ \\
\hline Frequency variation $\mathbf{( H z})$ & $922.7 \pm 38.73(631.6-1,210.8)$ & $1141.6 \pm 78.2(617.1-1,644.1)$ \\
\hline Central frequency $\mathbf{( H z )}$ & $4,393.6 \pm 76.6(3,807.1-4,964.9)$ & $5257.2 \pm 57.3(4,754.5-5,701.9)$ \\
\hline Peak frequency $(\mathbf{H z})$ & $4,420.7 \pm 80.1(3,812.8-5,014.1)$ & $5276.8 \pm 55.5(4,766.0-5,696.2)$ \\
\hline Note duration $(\mathbf{s})$ & $0.0217 \pm 0.0008(0.0153-0.0283)$ & $0.0169 \pm 0.0006(0.0130-0.0218)$ \\
\hline Rise time $(\mathbf{s})$ & $0.0103 \pm 0.0005(0.0050-0.0143)$ & $0.0042 \pm 0.0002(0.0027-0.0061)$ \\
\hline Fall time $(\mathbf{s})$ & $0.0115 \pm 0.0005(0.0071-0.0148)$ & $0.0126 \pm 0.0006(0.0087-0.0169)$ \\
\hline
\end{tabular}

Call duration $(s) \quad 0.1941 \pm 0.0043(0.1654-0.2273)$

Interval between notes $(s) \quad 0.1776 \pm 0.0044(0.1440-0.2132)$

Among all acoustic properties of note 1 , only note duration was more variable among individuals than within individuals (i.e., $\mathrm{CV}_{\mathrm{a}} / \mathrm{CV}_{\mathrm{w}}>1$ ). However, note 2 showed values above 1 for minimum frequency, frequency variation, center frequency, peak frequency, note duration, and fall time (Table 3). For both notes, spectral parameters were in general less variable than temporal parameters within and between individuals. The duration of the call and the interval between notes were also more variable among individuals than within individuals (see Table 3).

\section{Discussion}

Patterns of movement.-Male E. varleyi stayed in the same site for prolonged periods of time. Similar results have been reported in other species of frogs of different families (e.g., Martof 1953; Woolbright 1985; Crump 1986; Tessier et al. 1991; Kam and Chen 2000), with some individuals recaptured the following season less than two meters from the initial sampling site (Ovaska 1992; Kam and Chen 2000). However, other species covered long distances, mainly during the breeding season in search of bodies of water (Eggert et al. 1999; Lemckert and Brassil 2003; Goldberg and Schwalbe 2004; Greenberg and Tanner 2004; Neckel-Oliveira and Gascon 2006). Some species that have shown high fidelity to breeding sites (Dole and Duran 1974; Narvaes and Trefaut 2005; Smith and Green 2006) did not lose the trail even when artificially diverted from migratory routes (Vasconcelos and Calhoun 2004). According to Crump $(1986,1988)$ the fidelity to a specific area is determined by the availability of food, shelter, and breeding sites found by the resident in a known territory.

In our sampling in September, a trend to shorter movements was evident with respect to July. Male anurans spend

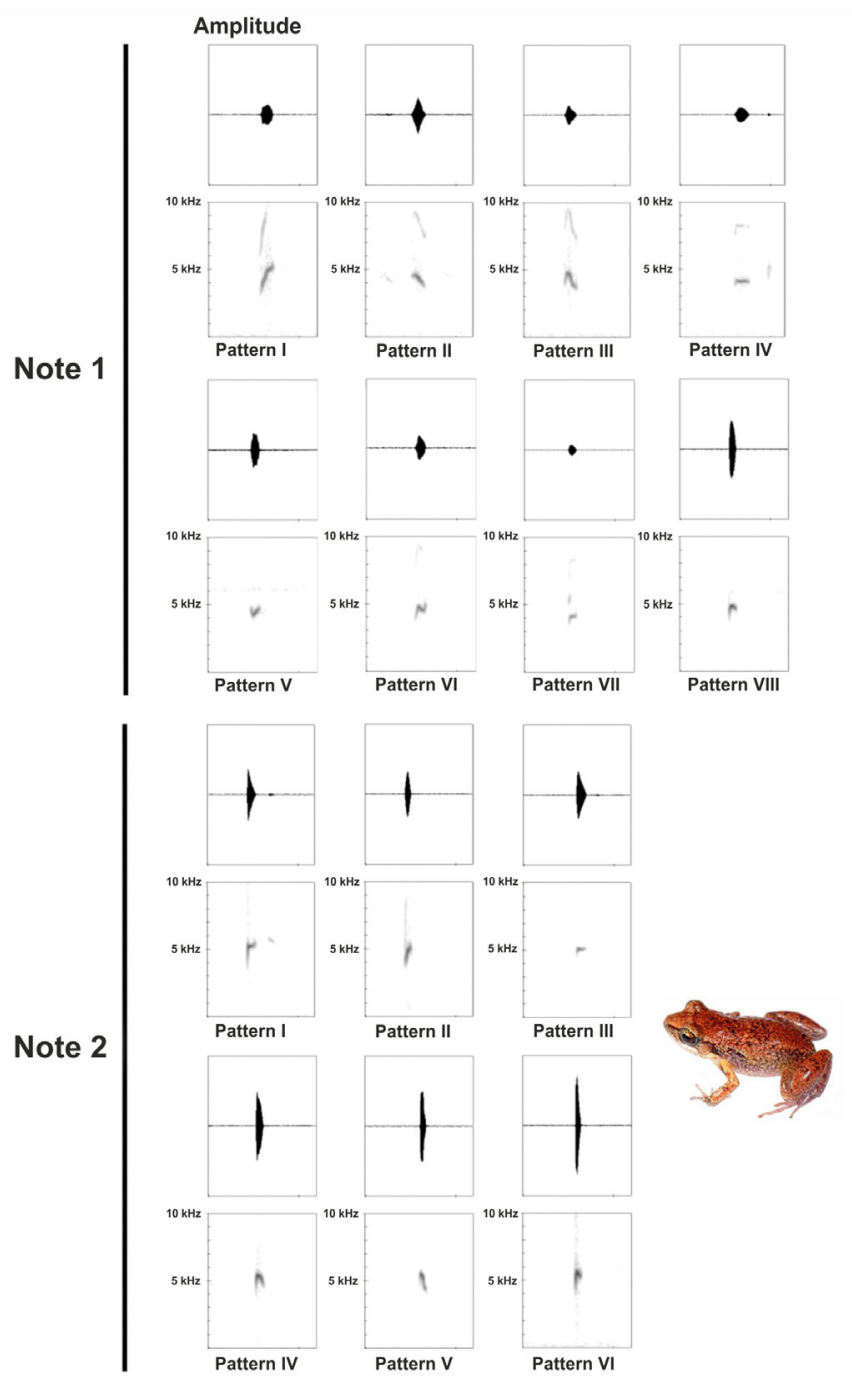

Fig. 7. Oscillograms and spectrograms of the advertisement calls of male Western Cuban Grassfrogs (Eleutherodactylus varleyi) in the National Botanical Garden of Cuba, Havana, Cuba. Photograph (C) Luis M. Díaz. 
Table 3. Coefficient of within-individual $\left(\mathrm{CV}_{\mathrm{w}}\right)$ and among-individual $\left(\mathrm{CV}_{\mathrm{a}}\right)$ variation of acoustic parameters of the advertisement call of male Western Cuban Grassfrogs (Eleutherodactylus varleyi) in a grassy area of the National Botanical Garden of Cuba, Havana, Cuba. ANOVA type I (F); statistically significant differences are indicated by an asterisk; alpha $=0.05$.

Acoustic parameters

Note 1

Note 2

$\begin{array}{llllllll}\mathrm{CV}_{\mathrm{w}} \text { mean (range) } & \mathrm{CV}_{\mathrm{a}} & \mathrm{CV}_{\mathrm{a}} / \mathrm{CV}_{\mathrm{w}} & \mathrm{F} & \mathrm{CV}_{\mathrm{w}} \text { mean (range) } & \mathrm{CV}_{\mathrm{a}} & \mathrm{CV}_{\mathrm{a}} / \mathrm{CV}_{\mathrm{w}} & \mathrm{F}\end{array}$

\begin{tabular}{|c|c|c|c|c|c|c|c|c|}
\hline Minimum frequency $(\mathrm{Hz})$ & $8.45(2.35-14.41)$ & 7.69 & 0.91 & $10.0^{*}$ & $6.83(3.22-10.58)$ & 9.61 & 1.41 & $27.1^{*}$ \\
\hline Maximum frequency $(\mathrm{Hz})$ & $7.42(3.17-11.07)$ & 7.10 & 0.96 & $13.0^{*}$ & $3.80(1.51-7.09)$ & 3.66 & 0.96 & $10.8^{*}$ \\
\hline Frequency variation $(\mathrm{Hz})$ & $34.96(19.08-59.30)$ & 18.30 & 0.52 & $3.8^{*}$ & $23.13(10.62-38.34)$ & 29.88 & 1.29 & $22.8^{*}$ \\
\hline Central frequency $(\mathrm{Hz})$ & $7.70(2.39-10.80)$ & 7.61 & 0.99 & $13.3^{*}$ & $4.19(1.51-7.80)$ & 4.75 & 1.13 & $15.5^{*}$ \\
\hline Peak frequency $(\mathrm{Hz})$ & $8.00(2.59-11.59)$ & 7.90 & 0.99 & $13.3^{*}$ & $4.07(1.51-8.20)$ & 4.59 & 1.13 & $14.7^{*}$ \\
\hline Note duration $(s)$ & $14.24(8.60-21.09)$ & 16.53 & 1.16 & $17.6^{*}$ & $12.64(6.50-23.10)$ & 17.04 & 1.35 & $24.2^{*}$ \\
\hline Rise time $(s)$ & $29.88(15.99-44.05)$ & 22.51 & 0.75 & $8.4^{*}$ & $28.48(13.70-52.60)$ & 25.11 & 0.88 & $9.4^{*}$ \\
\hline Fall time $(s)$ & $25.71(11.94-42.55)$ & 18.63 & 0.72 & $7.0^{*}$ & $18.04(8.30-33.70)$ & 21.62 & 1.20 & $18.7^{*}$ \\
\hline Call duration (s) & $7.08(3.78-14.98)$ & 9.83 & 1.39 & $23.5^{*}$ & & & & \\
\hline Interval between notes $(s)$ & $7.90(4.44-17.89)$ & 10.89 & 1.38 & $23.3^{*}$ & & & & \\
\hline
\end{tabular}

most of their time vocalizing (e.g., Duellman and Trueb 1994; Gerhardt 1994), which is a highly demanding energetic activity (e.g., Wells 2001; Ryan 2009). Since the acoustic activity of $E$. varleyi extends from May to December (personal observations of the authors), more comprehensive monitoring throughout the year and larger samples of individuals are necessary to test whether or not a temporal decrease in vocal activity exists.

The high number of movements observed during the first and final hours of the night could be related to the search for suitable sites to vocalize and the subsequent return to diurnal retreats. This bimodal pattern of activity has been reported for E. coqui (Woolbright 1985). Woolbright and Stewart (1987) argued that low levels of mobility during the intermediate hours of the night were linked to foraging activity, involving short movements associated with attempts to catch prey.

As for the pattern of movements along the vertical axis of the vegetation, we observed a nocturnal cycle of ascent and descent corresponding to the search for vocalization sites and refuges mentioned above. This same result was reported by Alonso et al. (2001) for E. eileenae, a species that vocalizes on vegetation several meters in height. These authors found that $76 \%$ of the males were on the ground in the early hours of the night and, as the night progressed, they began to ascend in the vegetation before descending back to their shelters just before dawn. The selection of elevated sites for vocalization is an adaptive response to minimize the attenuation effect of acoustic signals generated by the surrounding vegetation (Gerhardt 1994) and has been reported in numerous species of tropical anurans (Drewry 1970; Marten et al. 1977; Narins and Hurley 1982; Wells and Schwartz 1982; Stewart 1985).
Vocal activity.-The first peak of vocal activity occurred at nightfall, when both illumination and environmental temperatures decrease with a concomitant increase of the relative humidity. A second peak occurred just before dawn. These results are in agreement with Alonso et al. (2001) for E. eileenae. On the other hand, Woolbright (1985) found that the number of vocally active male E. coqui was very high in the early hours of the night and then gradually declined. Wells (1977) suggested that anurans respond to a reduction in light intensity, the stimulus that initiates acoustic activity in the first males of the chorus.

We found an apparent decrease in vocal activity between the two months sampled. Many studies have demonstrated the influence of environmental variables on vocalization patterns and general reproductive activity (e.g., Alonso et al. 2001; Greenberg and Tanner 2004; Saenz et al. 2006; Rodríguez et al. 2010). The decrease we observed could be due to the seasonal environmental variations or the physical exhaustion of males after several months of acoustic activity. However, the sample size of this study is very small. Larger samples involving more than one night and several months are required for testing one or both of these hypotheses.

During the nocturnal cycle, male E. varleyi vocalized in two different scenarios. In the first and last hours of the night, individuals generally vocalized while on or very near the ground, whereas in the intermediate hours they were high in the grass. This could be a reflection of differences in the behavioral context of advertisement calls emitted at different times of night. In congeners, the modification of advertisement calls, such us an increase in call rate or call duration and complexity has been reported (Stewart and Rand 1991, 
1992; Schwartz 1993; Ovaska and Caldbeck 1997; Alonso and Rodríguez 2001; Rodríguez et al. 2010). A high position in the vegetation should favor the transmission of the breeding message over a greater distance, suggesting that vocalizations could have a sexual meaning during intermediate hours of the night, whereas at the beginning and end of a nocturnal cycle, calls are likely to carry a territorial message directed to neighboring males. According to Stewart and Rand (1992), this acoustic variation allows for territorial positioning at dusk and the defense of the diurnal retreat at dawn. Male E. varleyi remaining in the same position during most of the night could indicate that females move to selected males. We did observe that males continued to vocalize as they descended to refugia at dawn. That these acoustic emissions accompanied by displacement have a reproductive component is unlikely. Instead, they almost certainly convey a territorial message.

Variability of the advertisement calls.-The patterns of frequency modulation previously described for note 1 were ascendant, descendant, inverted U-shaped, and unmodulated; whereas only the ascendant pattern was known for note 2 (Díaz et al. 2003, Díaz and Cádiz 2007, 2008). Herein we described four new patterns of frequency modulation for note 1 and five for note 2, demonstrating the remarkable variation that exists in the vocal repertoire of this species. According to Díaz and Cádiz (2007), 27\% of Cuban species do not present frequency modulations in their advertisement calls, 19\% have three modulation variants, and only $6 \%$ have between four and five patterns. The eight variants shown here clearly designate $E$. varleyi as one of the species of Cuban frogs with the greatest variability in the spectral design of its acoustic emissions.

The variation of the acoustic patterns of each note in $E$. varleyi could be suggestive of discrimination between neighbors, with note 2 making the greater contribution. However, according to Reinhold (2009), the duration effect of notes could be responsible for the increase in variation among the notes, a phenomenon that has been demonstrated in many species of frogs. In this study, note 2 was longer than note 1 ; consequently, an experimental design is required for ruling out this effect. On the other hand, note 2 showed greater among-individual variation of acoustic properties, which suggests that it could be a discriminatory element of the advertisement call. Nevertheless, the combination of both notes to form a call seems to bring certain distinctive characteristics to the individual because both call duration and note interval had values of the index of variability greater than one and also are among the parameters that contributed the most to the separation between groups. Searby and Jouventin, (2004) stated that the patterns of frequency modulation carry information within the social-recognition system and more complex calls with different spectral designs can potentially carry more information than those without frequency modulation.
Implications of movement patterns and variation in the advertisement call for the "dear-enemy" effect.-The low levels of mobility in $E$. varleyi could suggest the existence of an area that is occupied permanently (home range) at least during short periods in the breeding season. Territorial stability is strongly associated with discrimination between neighbors and therefore social recognition (Feng et al. 2009; Gasser et al. 2009; Bee et al. 2010). One of the fundamental requirements for social recognition is that vocalizations are distinctive among the social categories to which the emitters belong, serving effectively as "individual signatures" (Lesbarrères and Lodé 2002; Pettit et al. 2013). We can state only that males can be differentiated by their advertisement calls. Statistical estimates of individual variation can only be used to generate predictions about what could be the operative basis of the socialrecognition system among neighbors (Gasser et al. 2009; Bee et al. 2010; Pettitt et al. 2013). The design of playback experiments that evaluate the responses of males to the calls of both familiar individuals and strangers are needed to test the presence of the "dear-enemy" effect (Chuang et al. 2017).

\section{Acknowledgements}

We thank the National Botanical Garden of Cuba for logistical assistance during fieldwork. Special thanks go to Heivet Hernández for her help in the field work and with acoustic processing in the laboratory. We also thank Sonia Seuc, Mego Networks, Lima, Peru; Luis de Armas, Institute of Ecology and Systematics, Havana, Cuba; and Pedro P. Herrera, Institute of Tropical Geography, Havana, Cuba for critical reviews of the manuscript.

\section{Literature Cited}

Alonso Bosch, R. and A. Rodríguez Gómez. 2001. Llamadas del repertorio vocal de Eleutherodactylus eileenae (Anura: Leptodactylidae) del occidente de Cuba. Cuaderno de Herpetologia 14: 123-130.

Alonso, R., A. Rodríguez Gómez, and A.R. Estrada. 2001. Patrones de actividad acústica y trófica de machos cantores de Eleutherodactylus eileenae (Anura: Leptodactylidae). Revista Española de Herpetología 15: 45-52.

Alonso Bosch, R., A. Rodríguez Gómez, and M. Hernández Quinta. 2017. Advertisement call variation and individual acoustic distinctiveness in the explosive breeding toad Peltophryne cataulaciceps (Anura: Bufonidae). Acta Ethologica 20: 197-205.

Alonso, R., A. Rodríguez, and R. Márquez (eds.). 2007. Guía Sonora de los Anfibios de Cuba. Sound Guide of the Amphibians of Cuba. Alosa, Sons de la Natura and Fonoteca Zoologica, Madrid, Spain.

Bee, M.A., J.M. Cook, E.K. Love, L.R. O’Bryan, B.A. Pettitt, K. Schrode, and A. Vélez. 2010. Assessing acoustic signal variability and the potential for sexual selection and social recognition in Boreal Chorus Frogs (Pseudacris maculata). Ethology 116: 564-576.

Bee, M.A. and H.C. Gerhardt. 2001. Neighbour-stranger discrimination by territorial male Bullfrogs (Rana catesbeiana): I. Acoustic basis. Animal Behaviour 62: 1129-1140.

Bee, M.A., C.E. Kozich, K.J. Blackwell, and H.C. Gerhardt. 2001. Individual variation in advertisement calls of territorial male Green Frogs, Rana clamitans: Implications for individual discrimination. Ethology 107: 65-84.

Chuang, M.-F., Y.-C. Kam, and M.A. Bee. 2017. Territorial olive frogs display lower aggression towards neighbours than strangers based on individual vocal signatures. Animal Behaviour 123: 217-228. 
Crump, M.L. 1986. Homing and site fidelity in a Neotropical frog, Atelopus varius (Bufonidae). Copeia 1986: 438-444.

Crump, M.L. 1988. Aggression in harlequin frogs: male-male competition and a possible conflict of interest between the sexes. Animal Behaviour 36: 1064-1077.

Dautel, N., A.L. Salgado Maldanado, R. Abuza, H. Imba, K. Griffin, and J.M. Guayasamin. 2011. Advertisement and combat calls of the glass frog Centrolene lynchi (Anura: Centrolenidae), with notes on combat and reproductive behaviors. Phyllomedusa 10: 31-43.

Díaz, L.M. and A. Cádiz. 2007. Guía descriptiva para la identificación de las llamadas de anuncio de las ranas cubanas del género Eleutherodactylus (Anura: Leptodactylidae). Herpetotropicos 3: 100-122.

Díaz, L.M. and A. Cádiz. 2008. Guía Taxonómica de los Anfibios de Cuba. Abc Taxa, Brussels. Belgium.

Díaz, L.M., A. Cádiz, and S.B. Hedges. 2003. A new grass frog from pine forests of western Cuba, and description of acoustic and pattern variation in Eleutherodactylus varleyi (Amphibia: Leptodactylidae). Caribbean Journal of Science 39: 176-188.

Díaz, L.M., S.B. Hedges, and M. Schmid. 2012. A new cryptic species of the genus Eleutherodactylus (Amphibia: Anura: Eleutherodactylidae) from Cuba. Zootaxa 3220: 44-60.

Dole, J.W. and P. Durant. 1974. Movements and seasonal activity of Atelopus oxyrhynchus (Anura: Atelopodidae) in a Venezuelan cloud forest. Copeia 1974: 230-235.

Drewry, G.E. 1970. The role of amphibians in the ecology of the Puerto Rico rain forest, pp. 16-63. In: Puerto Rico Nuclear Center Annual Report No. 147. Center for Energy and Environment Research, San Juan, Puerto Rico.

Duellman, W.E. and L. Trueb. 1994. Biology of Amphibians. The Johns Hopkins University Press, Baltimore, Maryland, USA.

Eggert, C., P.-H. Peyret, and R. Guyétant. 1999. Two complementary methods for studying amphibian terrestrial movements, pp. 95-97. In: C. Miaud and R. Guyétant (eds.), Current Studies in Herpetology. Proceedings of the $9^{\text {th }}$ Ordinary General Meeting of the Societas Europaea Herpetologica, 25-29 August 1998, Le Bourget Dulac, France.

Feng, A.S., V.S. Arch, Z. Yu, X.-J. Yu, Z.-M. Xu, and J.-X Shen. 2009. Neighborstranger discrimination in Concave-Eared Torrent Frogs, Odorrana tormota. Ethology 115: 851-856.

Gasser, H., A. Amézquita, and W. Hödl. 2009. Who is calling? Intraspecific call variation in the aromobatid frog Allobates femoralis. Ethology 115: 596-607.

Gerhardt, H.C. 1994. The evolution of vocalization in frogs and toads. Annual Review of Ecology and Systematics 25: 293-324.

Goldberg, C.S. and C.R. Schwalbe. 2004. Habitat use and spatial structure of a Barking Frog (Eleutherodactylus augusti) population in southeastern Arizona. Journal of Herpetology 38: 305-312.

InfoStat. 2002. InfoStat versión 1.1. Grupo InfoStat, FCA, Universidad Nacional de Córdoba, Argentina.

Jang, Y., E.-H. Hahm, H.-J. Lee, S. Park, Y.-J. Won, and J.C. Choe. 2011. Geographic variation in advertisement calls in a tree frog species: Gene flow and selection hypotheses. PLoS ONE 6(8): e23297.

Kam, Y.-C. and T.-C. Chen. 2000. Abundance and movement of a riparian frog (Rana swinhoana) in a subtropical forest of Guandau Stream, Taiwan. Zoological Studies 39: 67-76.

Lemckert, F. and T. Brassil. 2003. Movements and habitat use by the Giant Burrowing Frog, Heleioporus australiacus. Amphibia-Reptilia 24: 207-211.

Lesbarrères, D. and T. Lodé. 2002. Variations in male calls and responses to an unfamiliar advertisement call in a territorial breeding anuran, Rana dalmatina: evidence for a "dear enemy" effect. Ethology Ecology \& Evolution 14: 287-295.

Marten, K., D. Quine, and P. Marler. 1977. Sound transmission and its significance for animal vocalization. II. Tropical forest habitats. Behavioral Ecology and Sociobiology 2: 291-302.

Martof, B. 1953. Home range and moments of the Green Frog, Rana clamitans. Ecology 34: 529-543.

Meuche, I., O. Brusca, K.-E. Linsenmair, A. Keller, and H. Pröhl. 2013. Only distance matters - non-choosy females in a poison frog population. Frontiers in Zoology 10: 29 (doi:10.1186/1742-9994-10-29).

Narins, P. M. and D.-D. Hurley. 1982. The relationship between call intensity and function in the Puerto Rican Coqui (Anura: Leptodactylidae). Herpetologica 38: $287-295$.
Narvaes, P. and M. Trefaut Rodrigues. 2005. Visual communication, reproductive behavior, and home range of Hylodes dactylocinus (Anura, Leptodactylidae). Phyllomedusa 4: 147-158.

Neckel-Oliveira, S. and C. Gascon. 2006. Abundance, body size and movement patterns of a tropical treefrog in continuous and fragmented forests in the Brazilian Amazon. Biological Conservation 128: 308-315.

Ovaska, K. 1992. Short and long-term movement of the frog Eleutherodactylus johnstonei in Barbados, West Indies. Copeia 1992: 569-573.

Ovaska, K.E. and J. Caldbeck. 1997. Vocal behaviour of the frog Eleutherodactylus antillensis on the British Virgin Islands. Animal Behaviour 54: 181-188.

Pettitt, B.A., G.R. Bourne, and M.A. Bee. 2013. Advertisement call variation in the Golden Rocket Frog (Anomaloglossus beebei): Evidence for individual distinctiveness. Ethology 119: 244-256

Pough, F.H., R.M. Andrews, M.L. Crump, A.H. Savitzky, K.D. Wells, and M.C. Brandley. 2016. Herpetology. $4^{\text {th }}$ ed. Sinauer Associates, Inc., Sunderland, Massachusetts, USA.

Reinhold, K. 2009. Variation of acoustic courtship signals in insects and amphibians: No evidence for bimodality, but identical dependence on duration. Ethology 115: 134-140.

Rodríguez, A., D. de la Nuez, and R. Alonso. 2010. Intraspecific variation in the advertisement call of the cloud-forest frog Eleutherodactylus glamyrus (Anura: Eleutherodactylidae). Journal of Herpetology 44: 457-466.

Rodríguez, A., Á. Dugo-Cota, S. Montero-Mendieta, A. Gonzalez-Voyer, R. Alonso Bosch, M. Vences, and C. Vilà. 2017. Cryptic within cryptic: genetics, morphometrics, and bioacoustics delimitate a new species of Eleutherodactylus (Anura: Eleutherodactylidae) from eastern Cuba. Zootaxa 4221: 501-522.

Rodriguez Forti, L., R. Márquez, and J. Bertoluci. 2015. Advertisement call of Dendropsophus microps (Anura: Hylidae) from two populations from southeastern Brazil. Zoologia 32: 187-194.

Rodriguez Forti, L., F.A.M. Martins, and J. Bertoluci. 2012. Advertisement call and geographical variation in call features of Dendropsophus berthalutzae (Anura: Hylidae) from the Atlantic rainforest of southeastern Brazil. Zootaxa 3310: 66-68.

Ryan, M.J. 2009. Communication in frogs and toads, pp. 1159-1166. In: L.R. Squire (ed.), Encyclopedia of Neuroscience, Volume 2. Academic Press, Oxford, UK.

Saenz, D., L.A. Fitzgerald, K.A. Baum, and R.N. Conner. 2006. Abiotic correlates of anuran calling phenology: The importance of rain, temperature, and season. Herpetological Monographs 20: 64-82.

Schwartz, J.J. 1993. Male calling behavior, female discrimination and acoustic interference in the Neotropical treefrog Hyla microcephala under realistic acoustic conditions. Behavioral Ecology and Sociobiology 32: 401-414.

Searby, A. and P. Jouventin. 2004. How to measure information carried by a modulated vocal signature? The Journal of the Acoustical Society of America 116: 3192-3198.

Smith, M.A. and D.M. Green. 2006. Sex, isolation and fidelity: unbiased longdistance dispersal in a terrestrial amphibian. Ecography 29: 649-658.

StatSoft. 2001. STATISTICA, Version 6.0. Statsoft, Inc., Tulsa, Oklahoma, USA.

Stewart, M.M. 1985. Arboreal habitat use and parachuting by a subtropical forest frog. Journal of Herpetology 19: 391-401.

Stewart, M.M. and A.S. Rand. 1991. Vocalization and the defense of retreat sites by male and female frogs, Eleutherodactylus coqui. Copeia 1991: 1013-1024.

Stewart, M.M. and A.S. Rand. 1992. Diel variation in the use of aggressive calls by the frog Eleutherodactylus coqui. Herpetologica 48: 49-56.

Tessier, C., D. Slaven, and D.M. Green. 1991. Population density and daily movement patterns of Hochstetter's frogs, Leiopelma hochstetteri, in a New Zealand mountain stream. Journal of Herpetology 25: 213-214.

Vasconcelos, D. and A.J.K. Calhoun. 2004. Movement patterns of adult and juvenile Rana sylvatica (LeConte) and Ambystoma maculatum (Shaw) in three restored seasonal pools in Maine. Journal of Herpetology 38: 551-561.

Vitt. L.J. and J.P. Caldwell. 2014. Herpetology: An Introductory Biology of Amphibians and Reptiles. $4^{\text {th }}$ ed. Academic Press, Cambridge, Massachusetts, USA.

Wells, K.D. 1977. The social behaviour of anuran amphibians. Animal Behavior 25: 666-693.

Wells, K.D. 2001. The energetics of calling in frogs, pp. 45-60. In: M.J. Ryan (ed.), Anuran Comunication. Smithsonian Institution Press, Washington, D.C., USA. 
Wells, K.D. 2007. The Ecology and Behavior of Amphibians. The University of Chicago Press, Chicago, Illinois, USA.

Wells, K.D. and J.J. Schwartz. 1982. The effect of vegetation on the propagation of calls in the Neotropical frog Centrollena fleischmanni. Herpetologica 38: 449-455.
Woolbright, L.L. 1985. Patterns of nocturnal movement and calling by the tropical frog Eleutherodactylus coqui. Herpetologica 41: 1-9.

Woolbright, L.L. and M.M. Stewart. 1987. Foraging success of the tropical frog, Eleutherodactylus coqui: The cost of calling. Copeia 1987: 69-75. 